\title{
Pengalihan Wakaf oleh Sarak Opat di Aceh Tengah Ditinjau Hukum Islam dan Hukum Adat
}

\author{
Djanuari, Hazar Kusmayanti, Divya Pratiwi \\ Fakultas Hukum Universitas Padjadjaran \\ Jl. Raya Bandung-Sumedang Km 21 Jatinangor Sumedang Jawa Barat \\ Email: hazar.kusmayanti@unpad.ac.id
}

\begin{tabular}{llll} 
Submit & $: 19$ Nopember 2019 & Diterima & $: 24$ September 2021 \\
Revisi & $: 14$ September 2020 & Terbit & $: 1$ Desember 2021 \\
\hline
\end{tabular}

\begin{abstract}
Waqf is one of the instrututions of Islamic sosial institutions that contain socio-economic value that are expected to help to realize social welfare that benefits can be enjoyed together. However, there are many problems related to waqfland, one of which is the change in the designation of waqf land based on adat meetings. The purpose of this thesis is to examine the legal position of waqf land that has changed its designation and implementation of waqf in Central Aceh District based on Islamic Law and Customary Law in terms of the Law. The research in this thesis uses the normative juridical approach The specification of the research conducted is analytical descriptive. Based on the results of this study, the legal status of waqf land that has been represented cannot be used if it is not in accordance with the waqf pledge, but there are exceptions to the waqf land that can be changed its designation and must follow the procedure for changes stipulated by Law Number 41 of 2004 Execution of existing land parcels in Central Aceh Regency, Islamic Law has been implemented correctly, but the state administration has not been implemented to the maximum.
\end{abstract}

Keywords: waqf, Islamic law, traditional law, Sarak Opat, Aceh Tengah

Abstrak: Wakaf merupakan salah satu institusi atau pranata sosial Islam yang mengandung nilai sosial ekonomi yang diharapkan mampu membantu untuk mewujudkan kesejahteraan sosial yang manfaatnya dapat dinikmati secara bersama-sama. Namun banyak permasalahan terkait tanah wakaf ini salah satunya perubahan peruntukan tanah wakaf berdasarkan musyawarah adat. Tujuan penelitian ini untuk mengkaji kedudukan hukum tanah wakaf yang telah berubah peruntukannya dan pelaksanaan wakaf di Kabupaten Aceh Tengah ditinjau dari Hukum Islam dan Hukum Adat. Penelitian dalam penulisan ini menggunakan metode pendekatan yuridis normatif. Spesifikasi penelitian yang dilakukan adalah deskriptif analitis. Berdasarkan hasil penelitian ini, kedudukan hukum tanah wakaf yang telah diwakafkan tidak dapat dipergunakan apabila tidak sesuai dengan ikrar wakaf, namun ada pengecualian tanah wakaf bisa dirubah peruntukannya dan harus mengikuti prosedur perubahan yang ditetapkan oleh Undang-Undang Nomor 41 Tahun 2004. Pelaksanaan perwakafan tanah yang ada di Kabupaten Aceh Tengah secara Hukum Islam telah terlaksana dengan benar, namun secara Administrasi Negara belum terlaksana dengan maksimal.

Kata Kunci: wakaf, hukum Islam, hokum adat, Sarak Opat, Aceh Tengah, 


\section{Pendahuluan}

Lembaga wakaf sudah dikenal semenjak Islam masuk ke nusantara dan diterima baik oleh masyarakat, bahkan pakar hukum Ter Haar mengemukakan bahwa wakaf telah diterima baik dan sempurna dalam sistem hukum adat (gerecipeerd). Hal tersebut sangat wajar mengingat sebagian besar penduduk Indonesia beragama Islam, inilah salah satu dari bagian hukum adat yang berasal agama (goodienstig bestaandeel van het adat recht). ${ }^{1}$ Wakaf merupakan salah satu tuntutan ajaran Islam yang menyangkut kehidupan bermasyarakat dalam rangka ibadah sosial, karena wakaf adalah ibadah, maka tujuan utamanya adalah pengabdian kepada Allah SWT dan ikhlas karena mencari ridha Allah. ${ }^{2}$ Walaupun wakaf sebagai tuntutan dari ibadah sosial tetapi dalam praktiknya harus dilakukan dengan peraturan syariat Islam dan peraturan perundang-undangan yang berlaku yaitu UndangUndang Nomor 41 Tahun 2004 Tentang Wakaf (yang selanjutnya disebut Undang-Undang Wakaf).

Perwakafan merupakan salah satu hal yang sering terjadi dalam masyarakat. Dalam perwakafan banyak terjadi permasalahan terkait keabsahan status wakaf tersebut, yang harus memerlukan kajian secara yuridis. Di Indonesia pada umumnya wakaf dipandang sebagai institusi keagamaan. Dengan sendirinya masalah wakaf bukan sekedar masalah keagamaan atau masalah adat belaka melainkan juga masalah kemasyarakatan dan individu secara keseluruhan yang menyangkut masalah-masalah sosial, ekonomi, kemasyarakatan, administrasi, bahkan juga masalah politik. Hal ini membawa konsekuensi pada perwakafan di Indonesia. ${ }^{3}$

Al-Quran tidak disebutkan secara eksplisit dan jelas, serta tegas tentang wakaf. Alquran hanya menyebutkan dalam artian umum, bukan khusus menggunakan kata wakaf. Tetapi para ulama fikih menjadikan ayat-ayat umum itu sebagai dasar hukum wakaf dalam Islam, seperti ayat-ayat yang membicarakan tentang kebaikan, șadaqah, infäk dan amal jāriyah. Para ulama menafsirkan bahwa wakaf sudah tercakup dalam ayat-ayat umum itu, antara lain Q.S. al Hajj ayat 77 dan al-Baqarah ayat $261 .^{4}$

Wakaf telah disyariatkan dan telah dilaksanakan oleh umat Islam sejak masa Nabi Muhammad Saw. Namun, wakaf yang sangat populer di kalangan umat Islam, khususnya di Indonesia masih terbatas pada seputar persoalan tanah dan bangunan yang diperuntukkan untuk tempat ibadah dan pendidikan, atau bangunan sosial lainya.

Salah satu objek wakaf adalah perwakafan tanah, hal ini terlepas dari peran tanah itu sendiri yaitu sebagai tempat tinggal, tempat kegiatan kesehatan, tempat kegiatan ibadah dan lain-lain. Hak atas tanah termasuk salah satu hak perseorangan atas tanah. Hak perseorangan atas tanah adalah hak yang memberi wewenang kepada pemegang haknya (perseorangan, sekelompok orang secara bersama-sama, badan hukum) untuk memakai, dalam arti menguasai, menggunakan, dan/atau mengambil manfaat dari tanah tertentu ${ }^{5}$. Untuk memperoleh tanah tersebut dapat diperoleh dengan cara jual-beli, tukar-menukar, sewa menyewa, pinjam-meminjam, dan dapat diperoleh juga dengan wakaf.

\footnotetext{
Ter Haar, Asas-asas dan Susunan Hukum Adat (Jakarta: Pradnya Paramita, 1983), 61.

Abdul Ghofur Anshori, Hukum dan Praktik Perwakafan di Indonesia, (Yogyakarta: Pilar Media, 2005), 1.

Rachmadi Usman, Hukum Perwakafan di Indonesia (Jakarta: Sinar Grafika, 2009), 9-10.

Syarif Hidayatullah, "Wakaf Uang dalam Perspektif Hukum Islam dan Hukum Positif di Indonesia”, Salam: Jurnal Sosial \& Budaya Syar-i, Vol. 3 No. 1 (2016), 1-20.

5 Mira Novana Ardani, "Kepemilikan Hak Atas Tanah bagi Orang Asing di Indonesia.” Jurnal Law Reform Vol. 13, No. 2, (2017), 207.
} 
Pada awalnya dasar hukum lembaga wakaf yang utama terdapat dalam kitab suci Al-Quran saja. Namun sebagai negara hukum, Indonesia menjunjung tinggi asas legalitas, segala sesuatunya berdasarkan hukum dan peraturan perundang-undangan yang berlaku. Kebiasaan atau tradisi untuk menjadi hukum diperlukan dua unsur yaitu selain pola tindak yang berulang itu sebagai sesuatu hal yang dipatuhi diterima sebagai aturan yang mengikat (opinion iuris necessitates). ${ }^{6}$

Status hukum yang pasti bagi tanah wakaf sangat penting artinya antara lain bagi pemanfaatan tanah wakaf sehingga sesuai dengan tujuan perwakafan itu sendiri. Pelaksanaan hukum perwakafan di Indonesia semula masih sangat sederhana tidak disertai administrasi, cukup dilakukan ikrar (pernyataan) secara lisan. Pengurusan dan pemeliharaan tanah wakaf kemudian diserahkan ke nazhir. Oleh karena tidak tercatat secara administratif, maka banyak tanah wakaf tidak mempunyai bukti perwakafan sehingga banyak tanah wakaf yang hilang dan banyak pula yang menjadi sengketa di pengadilan. ${ }^{7}$

Dalam mewakafkan harta tetap saja tunduk pada pengaturan yang terdapat dalam Al-Quran dan ketentuan ketentuan fiqih. Pengaturan yang jelas dan terperinci mengenai wakaf baru dibuat oleh Pemerintah Negara Indonesia melalui Undang-Undang No.41 Tahun 2014 Tentang Wakaf. Dalam menciptakan tertib hukum dan administratif wakaf untuk melindungi benda wakaf, maka oleh karena itu Pemerintah mengesahkan dan memberlakukan Undang-Undang Wakaf. Lahirnya Undang-Undang Wakaf ini didasarkan pada keprihatinan terhadap pengelolaan dan pengembangan wakaf di Indonesia. ${ }^{8}$

Tanah wakaf merupakan peralihan hak pribadi, hak milik, atau badan hukum tertentu, dialihkan menjadi hak wakaf tujuannya untuk keperluan sosial, ibadah dan keperluan umum lainya. Perwakafan tanah sering kemajuan yang terjadi dalam masyarakat, dilakukan di depan atau badan yang berwenang dalam Pembuatan Akta Ikrar Wakaf (yang selanjutnya disebut AIW). Tiap Kantor Urusan Agama (yang selanjutnya disebut KUA) berwenang membuat AIW bersama dengan Badan Pertanahan Nasional (yang selanjutnya disebut BPN).

Pada prinsipnya tanah wakaf yang telah bersetifikat tidak dapat dilakukan perubahan terhadap peruntukkannya atau penggunaannya selain dari yang telah ditentukan dalam ikrar. Maka berdasarkan hal tersebut wakaf selama-lamanya bersifat abadi dengan jangka waktu tidak terbatas dan wakaf yang diikrarkan tidak dapat dibatalkan, maka pada dasarnya wakaf tersebut tidak dapat dilakukan perubahan peruntukannya terkecuali jika mendapatkan persetujuan dan didaftarkan kembali dengan mengubah ikrar yang telah terdaftar sebelumnya.

Pengaturan yang terdapat dalam Al-Quran dan hukum positif di Indonesia mengenai wakaf sudah cukup jelas, namun selalu ada perbedaan antara seharusnya terjadi dengan kenyataan dalam masyarakat. Berdasarkan penjelasan yang diberikan oleh Kepala bidang (Kabid) Zakat dan Wakaf (Selanjutnya disebut ZAWA) di Kantor Departemen Agama Kabupaten Aceh Tengah bahwa tanah wakaf yang berada di wilayah Kabupaten Aceh Tengah telah peruntukanya telah sesuai dengan ikrar wakaf. Akan tetapi setelah dilihat ke kecamatan tersebut, terdapat tanah wakaf atau objek wakaf yang ternyata tidak sesuai peruntukannya dengan ikrar wakaf yang telah didaftarkan, seperti di

\footnotetext{
6 Mochtar Kusumaatmadja dan B. Arief Sidharta, Pegantar Ilmu Hukum Suatu Pengenalan Pertama Ruang Lingkup Berlakunya Hukum (Bandung: Alumni, 2000), 66

7 Imam Suhadi, Wakaf Untuk Kesejahteraan Umat (Yogyakarta: Dana Bhakti Prima Jasa, 2002), 6.

8 Imam Suhadi, 8.
} 
Kecamatan Kute Panang dan Kecamatan Bebesan. Kasus ini bermula ketika Seh Jali mewakafkan tanah di Desa Keramat Mupakat Kecamatan Bebesan yang mana peruntukan tanah tersebut diwakafkan dengan peruntukan yang dikehendaki oleh wakif adalah untuk jalan umum. Pada hal ini Seh Jali mewakafkan tanah tersebut kepada lembaga adat Sarak Opat yang mana di Akta Ikrar Wakaf tertera bahwa tanah yang diwakafkan oleh Seh Jali sebagai jalanan umum. Tanah wakaf yang seharusnya digunakan sebagai jalan umum namun sekarang tanah wakaf ini berubah peruntukannya menjadi dermaga kapal. Hal ini dikarenakan Pemerintah Kabupaten Aceh Tengah pada saat itu membutuhkan lokasi tanah yang digunakan untuk dermaga kapal dan lokasi tanah wakaf yang diwakafkan oleh Seh Jali tersebut lokasinya lebih baik digunakan sebagai dermaga kapal.

Berdasarkan penjelasan nadir Desa Keramat Mupakat Kecamatan Bebesan tanah tersebut memang pada dasarnya diwakafkan untuk jalan umum, sekarang tanah tersebut telah berubah atau berganti peruntukannya untuk dermaga kapal yang mana pada saat ini digunakan oleh Pemerintah Kabupaten Aceh Tengah. Terkait tanah wakaf semula, Pemerintah Kabupaten Aceh Tengah telah mengganti dengan tanah wakaf lainnya sebagai pengganti tanah wakaf sebelumnya yang telah digunakan artinya Pemerintah Kabupaten Aceh Tengah, membeli sebidang tanah yang sama dengan luas dari tanah yang telah digunakan sebelumnya sebagai pengganti tanah wakaf tersebut dan sudah diterima oleh pihak KUA Kecamatan Bebesan sebagai tanah wakaf yang baru dengan peruntukkan yang semula yaitu sebagai jalan umum.

Akan tetapi seiring berjalannya waktu saat sekarang ini tanah wakaf tersebut tidak diperuntukan lagi untuk jalan umum dan sekarang tanah wakaf tersebut diperuntukan untuk keperluan ibadah (menasah) Desa Keramat Mupakat, tanpa adanya perubahan yang dilakukan di dalam Akta Ikrar Wakaf sebelumnya dan dilakukan hanya berdasarkan musyawarah yang disepakati oleh lembaga adat Sarak Opat.

Permasalahan yang timbul dalam masyarakat adalah peruntukan tanah wakaf yang tidak sesuai dengan ikrar wakaf yang didaftarkan, sehingga dalam hal seperti ini terjadi pelanggaran syariat dan bertentangan dengan Undang-Undang Nomor 41 Tahun 2004 Tentang Wakaf maupun berdasarkan Hukum Islam. Penelitian mengenai Tanah Wakaf yang dialihkan peruntukannya oleh Lembaga Adat Sarak Opat ditinjau dari Hukum Islam dan Hukum Adat

\section{Kedudukan Hukum Tanah Wakaf yang Dialihkan Peruntukannya oleh Lembaga Adat Sarak Opat di Kabupaten Aceh Tengah Ditinjau dari Hukum Islam dan Hukum Adat}

Dalam fiqih Islam wakaf digolongkan dalam akad tabarru' yakni janji melepas hak tanpa suatu imbalan kebendaan yang ditujukan kepada Allah SWT dalam rangka beribadah dan mengharapkan keridhaannya. Dalam melakukan aqad perlunya pernyataan (sighat) wakif yang merupakan tanda penyerahan barang atau benda yang diwakafkan itu kepada pengelola wakaf atau nadir yang dapat dilakukan secara lisan maupun tulisan yang dituangkan dalam ikrar wakaf. Dengan sighat wakaf itu mulailah perjanjian antara wakif dengan nadir dalam pemanfaatan benda wakaf. Sighat wakif juga melambangkan bahwa hak wakif atas benda yang diwakafkannya itu menjadi hak mutlak milik Allah SWT yang akan dimanfaatkan dalam ikrar wakaf.

Dalam Pasal 23 Undang-Undang Nomor 41 Tahun 2004 Tentang Wakaf penetapan peruntukan harta benda wakaf sebagaimana dimaksud dalam Pasal 22 dilakukan oleh Wakif pada pelaksanaan 
ikrar wakaf. Menurut ketentuan dalam Pasal 11 ayat (1) Peraturan Pemerintah Nomor 28 Tahun 1977 Tentang Perwakafan Tanah Milik pada dasarnya terhadap tanah milik yang telah diwakafkan tidak dapat dilakukan perubahan peruntukkan atau penggunaan lain dari pada yang dimaksud Ikrar Wakaf. Dalam hal ini tidak berarti dalam hal-hal tertentu tidak dapat dilakukan perubahan perwakafan tanah milik.

Perubahan peruntukan tanah yang dilakukan tidak sesuai dengan Undang-Undang Nomor 41 Tahun 2004 Tentang Wakaf dan Peraturan Pemerintah Nomor 28 Tahun 1977 Tentang Perwakafan Tanah Milik. Perwakafan yang dilakukan oleh si wakif tidak ada unsur keterpaksaan dan tidak ada kata perubahan peruntukan dan penggantian harta benda wakaf pada saat dilakukan ikrar. Dan apabila ada perubahan yang dilakukan itu jelas tidak sesuai dengan Pasal 23 ayat (1) Undang-Undang Nomor 41 Tahun 2004 Tentang Wakaf.

Dalam ketentuan Pasal 11 ayat (2) Peraturan Pemerintah Nomor 28 Tahun 1977 Tentang Perwakafan Tanah Milik ditentukan bahwa penyimpangan dari ketentuan tersebut dalam ayat (1) hanya dapat dilakukan terhadap hal-hal tertentu setelah terlebih dahulu mendapat persetujuan tertulis dari Menteri Agama yaitu:

1. Karena tidak sesuai lagi dengan tujuan wakaf seperti yng diikrarkan oleh wakif

2. Karena kepentingan umum

Berbagai penyimpangan dari ketentuan tersebut dalam Pasal 11 ayat (2) Peraturan Pemerintah Nomor 28 Tahun 1977 Tentang Perwakafan Tanah Milik disamping terkena sanksi seperti dimaksud dalam Pasal 15 Peraturan Pemrintah Nomor 28 Tahun 1977 Tentang Perwakafan Tanah Milik juga perbuatan itu batal dengan sendirinya menurut hukum. Menurut ketentuan Pasal 13 ayat (3) Peraturan Menteri Agama Nomor 1 Tahun 1978 Peraturan Pelaksanaan Peraturan Pemerintah Nomor 28 Tahun 1977 Tentang Perwakafan Tanah Milik perubahan status tanah wakaf dapat diizinkan apabila diberikan pergantian yang sekurang-kurangya senilai dan seimbang dengan kegunaannya sesuai dengan Ikrar Wakaf.

Perubahan status tanah milik yang telah diwakafkan dan perubahan penggunaannya sebagai akibat dari penyimpangan karena dilakukan dalam hal-hal tertentu maka nadir ¡berkewajiban untuk melaporkannya kepada Bupati/Walikota Kepala Kantor Pertanahan setempat untuk mendapatkan penyelesaian lebih lanjut. Dalam konteks muamalah, kebenaran wakif, nadir, saksi dan Pejabat Pembuat Akta Ikrar Wakaf (PPAIW) merupakan keniscayaan demi menjamin kepastian hukum, terutama dalam hal kepemilikan, beban (antara pihak lain pajak), dan pendayagunaan objek wakaf.

Pada waktu yang lampau, sebelum dikeluarkan Peraturan Pemerintah Nomor 28 Tahun 1977 Tentang Perwakafan Tanah Milik perubahan status tanah-tanah yang diwakafkan dapat dilakukan begitu saja oleh nadir tanpa alasan-alasan yang meyakinkan. Padahal nadir sebagai pihak yang ditunjuk menjadi pengurus tanah wakaf haruslah seseorang yang dapat dipercaya untuk menjalankan amanah mengurus tanah wakaf sesuai dengan yang dimaksudkan oleh wakif dan memiliki tanggung jawab bila sengaja merusak benda wakaf atau lalai mengurusnya. Kewenangan nadir dalam mengurus dan mengelola harta benda wakaf telah ditentukan oleh Undang-Undang Wakaf. Pasal 11 huruf b menyebutkan bahwa nadir mempunyai tugas mengelola dan mengembangkan harta benda wakaf sesuai dengan tujuan, fungsi dan peruntukannya,

Menurut Pasal 40 Undang-Undang Nomor 41 Tahun 2004 Tentang Wakaf juga mengatur 
tentang perubahan dan pengalihan harta wakaf yang sudah dianggap tidak atau kurang berfungsi sebagaimana maksud wakaf itu sendiri. Secara prinsip, harta benda wakaf yang sudah diwakafkan dilarang: Dijaminkan jaminan, Disita, Dihibahkan, Dijual, Diwariskan, Ditukar. Dialihkan.

Dalam ketentuan Pasal 40 Undang-Undang Nomor 41 Tahun 2004 Tentang Wakaf tersebut melarang harta benda wakaf terutama tanah wakaf utnuk diubah statusnya, namun dikecualikan dalam Undang-Undang Nomor 41 Tahun 2004 Tentang Wakaf. Menurut Pasal 41 ayat (1) UndangUndang Nomor 41 Tahun 2004 Tentang Wakaf, pengecualian atas perubahan atas status tanah wakaf dapat dilakukan apabila harta benda wakaf yang telah diwakafkan digunakan untuk kepentingan umum sesuai dengan Rencana Umum Tata Ruang (RUTR). Berdasarkan ketentuan dan peraturan perundang-undangan yang berlaku dan tidak bertentangan dengan syari'ah. Pelaksanan ketentuan sebagaimana dimaksud pada ayat (1) hanya dapat dilakukan setelah memperoleh izin tertulis dari Menteri atas persetujuan Badan Wakaf Indonesia.

Berdasarkan permasalahan kasus pertama yakni yang terjadi Desa Keramat Mupakat Kecamatan Bebesan yang mana peruntukan tanah tersebut diwakafkan dengan peruntukan untukjalanan umum dan tertera di dalam akta wakaf untuk jalanan umum namun sekarang tanah tersebut dijadikan sebagai dermaga kapal. Dalam hal ini pemerintah Kabupaten Aceh Tengah membutuhkan tanah tersebut sebagai dermaga kapal. Pemerintah Kabupaten Aceh Tengah juga mengganti dengan tanah lain yang setara dengan tanah yang digunakan sebagai dermaga kapal tersebut.

Perubahan peruntukan seperti dalam kasus tersebut dapat dilakukan karena walaupun pada dasarnya tanah wakaf tidak boleh di tukar ataupun dialihkan tetapi hal tersebut dapat dikecualikan apabila demi kepentingan umum, dan dalam kasus ini hal tersebut digunakan sebagai dermaga kapal yang mana hal tersebut demi kepentingan masyarakat banyak. Permasalahan ini juga sesuai dengan peraturan-perundang undangan yakni Pasal 41 ayat (1) Undang-Undang Nomor 41 Tahun 2004 Tentang Wakaf. Pemerintahan Kabupaten Aceh Tengah juga mengganti tanah yang telah digunakan dengan tanah yang setara dengan tanah yang ditukar tersebut dan perubahan peruntukannya telah diserahkan kepada KUA Kecamatan Bebesan.

Permasalahan yang muncul kemudian adalah tanah yang sudah diganti oleh Pemerintah Kabupaten Aceh tersebut yang awalnya sebagai jalan umum sekarang peruntukannya tidak lagi sebagai jalanan umum melainkan sebagai keperluan ibadah (menasah) tetapi di dalam Akta Ikrar Wakafnya masih sebagai jalanan umum. Dalam Pasal 41 ayat (1) Undang-Undang Nomor 41 Tahun 2004 Tentang Wakaf mewajibkan bahwa tanah wakaf yang ditukar harus sesuai dengan ketentuan syariah.

Tanah wakaf yang telah berubah peruntukannya terdapat dalam prakteknya, tanah wakaf ini diubah peruntukannya disebabkan karena tanah tidak sesuai dengan yang diinginkan atau kurang strategis untuk hal tertentu. Pada kasus kedua yang terdapat di Desa Wih Nongkal Kecamatan Kute Penang. Berdasarkan penjelasan kepala desa Wih Nongkal tanah wakaf yang diwakafkan oleh Merheje tanah wakaf tersebut pada awalnya diperuntukan untuk menasah (masjid) namun diganti peruntukkannya menjadi sebagai tempat pengajian lalu karena tidak dapat berfungsi dengan baik ketika dijadikan sebagai tempat pengajian kemudian diganti lagi sebagai area perkuburan, yang mana perubahan dilakukan sebanyak 3 (tiga) kali dan dari awal peruntukan maupun perubahan tidak terdapat akta ikrar wakaf didalamnya hanya dilakukan secara adat saja.

Proses perubahan peruntukan tanah wakaf yang terjadi di Desa Wih Nongkal ini hanya 
berdasarkan musyawarah adat desa saja, hal seperti ini sudah sering terjadi karena tanah wakaf tersebut tidak pernah di daftarakan ke Kantor Urusan Agama dan proses Perwakafan hanya berdasarkan proses adat saja yaitu dengan mengucapkan lisan kepada dan disaksikan oleh beberapa orang sebagai saksi maka Perwakafan dianggap sah. Hal ini pun dibenarakan oleh Kepala Kantor Urusan Agama, bahwa ada pertukaran tanah wakaf hanya dengan musyawarah desa saja, hal ini karena memang tanah wakaf tersebut belum pernah didaftarkan kepada Kantor Urusan Agama sehingga masyarakat dengan mudahnya menukar tanah wakaf tersebut dengan tanah wakaf lainnya.

Tanah wakaf tersebut tidak sah penggunaannya karena dilakukan hanya berdasarkan musyawarah desa, tidak berdasarkan pada Peraturan Pemerintah Nomor 42 Tahun 2006 Tentang Pelaksanaan Undang-Undang Nomor 41 Tahun 2004 Tentang Wakaf, pada Pasal 49 menyatakan bahwa perubahan status harta benda wakaf dalam bentuk penukaran dilarang kecuali dengan izin tertulis dari Menteri berdasarkan pertimbangan Badan Wakaf Indonesia (BWI). Menurut Peraturan Pemerintah Nomor 42 Tahun 2006 Tentang Pelaksanaan Undang-Undang Nomor 41 Tahun 2004 Tentang Wakaf tersebut, bahwa penukaran harta benda wakaf dalam bentuk penukaran dilarang, tetapi dengan pengecualian harus ada izin tertulis dari Menteri yang berwenang dalam masalah pertanahan.

Pemerintah telah mengeluarkan dan memberlakukan peraturan perundang-undangan khusus yang mengatur tentang wakaf. Namun, sengketa dan penyimpangan terkait dengan wakaf masih sering terjadi. Hal ini disebabkan tidak hanya kelalaian atau ketidakmampuan nadir dalam mengelola dan mengembangkan harta benda wakaf, melainkan masyarakat yang belum berperan aktif dalam meningkatkan kegiatan wakaf sebagai sarana untuk membangun kesejahteraan masyarakat di Indonesia. Selain itu wakif biasanya masih menggunakan kebiasaan-kebiasaan lama dengan melakukan wakaf tanpa disertai Akta Ikrar wakaf dan sertifikat Harta Wakaf.

Bukti otentik yang tidak ada akan membuat kedudukan harta benda wakaf termasuk tanah wakaf tidak memiliki kekuatan dan kepastian hukum. Oleh karena itu, untuk menghindari hal-hal yang dapat merugikan serta mencegah terjadinya penyalahgunaan harta benda wakaf dari fungsi dan tujuan wakaf karena peran nadir yang tidak professional seperti dalam kasus Mengelola tanah wakaf merupakan tugas nazhir dan pengelolaannya diawasi oleh Badan Wakaf Indonesia. Pasal 11 Undang-undang Nomor 41 Tahun 2004 menyatakan bahwa nazhir mempunyai tugas yaitu Melakukan pengadministrasian harta benda wakaf; Mengelola dan mengembangkan harta benda wakaf sesuai dengan tujuan, fungsi dan peruntukannya; Mengawasi dan melindungi harta benda wakaf; Melaporkan pelaksanaan tugas kepada Badan Wakaf Indonesia. Melalui Pasal ini dapat dilihat bahwa Nazir dan Badan Wakaf Indonesia mempunyai hubungan fungsional terhadap pengelolaan harta benda wakaf guna untuk mengembangkan pengelolaan wakaf ke arah yang lebih profesional dan produktif sehingga wakaf benar-benar mampu memberikan sumbangan perekonomian bagi umat Islam khususnya. ${ }^{9}$

Posisi tanah wakaf lemah secara hukum disebabkan karena tidak adanya akta ikrar wakaf dan sertifikat wakaf, apabila tanah wakaf tersebut tidak didaftarkan dan tidak disertifikasi, maka tanah wakaf tersebut tidak dapat terlindungi oleh hukum yang berlaku karena tidak ada bukti yang kuat

\footnotetext{
9 Syaddan Dintara Lubis, Muhammad Yamin Lubis, Utary Maharany Barus, Rosnidar Sembiring, "Hubungan Hukum Pengelolaan Wakaf antara Nazhir dan Badan Wakaf Indonesia Provinsi Sumatra Utara terhadap Tanah Wakaf yang Belum Terdaftar: Studi di Kota Medan", USU Law Journal, Vol. 3, No. 3 November (2015), 189.
} 
bahwa tanah tersebut telah diwakafkan yang seharusnya dilindungi agar tanah yang diwakafkan tersebut dapat dimanfaatkan sesuai dengan tujuan wakaf. Berdasarkan Pasal 19 ayat (2) huruf c UUPA dan Pasal 32 ayat (1) PP 24/1997 bahwa sertifikat yang merupakan surat bukti hak atas tanah berlaku sebagai alat pembuktian yang kuat. Oleh karena data dalam sertifikat mencakup data mengenai jenis haknya, subjeknya maupun mengenai letak, batas, dan luasnya maka sertifikat memberikan jaminan kepastian hukum terhadap data tersebut. ${ }^{10}$ Apabila sertifikasi dilakukan terhadap tanah wakaf, maka tanah wakaf tersebut memiliki status hukum dan dapat mendapatkan kepastian hukum dan jika ada pihak yang akan mengambil tanah tersebut, dapat dituntut berdasarkan hukum yang berlaku.

Kegiatan wakaf yang tidak didaftarkan dianggap tidak ada, walaupun kegiatan wakaf tersebut sudah sah menurut agama, tetap saja dianggap tidak sah selama wakaf tersebut belum didaftarkan melalui akta ikrar wakaf yang dibuat oleh Pejabat Pembuat Akta Wakaf (PPAIW). Kegiatan wakaf yang tidak didaftarkan sangatlah lemah kedudukannya karena tidak mendapat perlindungan hukum sama sekali.

Pembuatan akta otentik termasuk didalamnya sertifikasi atas tanah wakaf harus dilakukan dalam rangka memberikan suatu kepastian hukum dan setidaknya mencegah adanya sengketa tanah wakaf dikemudian hari, sehingga diharapkan tidak akan terjadi hal-hal yang tidak diharapkan atas tanah wakaf tersebut. Akta PPAT dibuat sebagai tanda bukti. Fungsinya adalah untuk memastikan suatu peristiwa hukum, dengn tujuan menghindarkan sengketa. Oleh karena itu, pembuat akta diharapkan agar aktanya itu tidak memuat rumusan-rumusan yang dapat menimbulkan sengketa karena tidak lengkap dan tidak jelas. Untuk mewujudkan pengakuan dan perlindungan, maka tanah wakaf yang telah ada harus ditertibkan guna memudahkan pengawasan dan agar praktek perwakafan tersebut dapat dilaksanakan sesuai dengan fungsi dan tujuan wakaf secara optimal. ${ }^{11}$

Oleh karena itu pengalihan fungsi peruntukan tanah wakaf dalam pandangan hukum islam dapat dibenarkan bila alasan-alasannya telah sesuai dengan ketentuan yang berlaku. Bahwa dalam Hukum islam diadakannya pembenaran peruntukan atau pengalihan tanah wakaf dengan syarat bahwa tanah wakaf yang telah dialihkan tersebut memang mempunyai manfaat yang jauh lebih bermanfaat yang jauh lebih baik demi kemaslahatan umat atau kepentingan umum.

Perubahan peruntukan yang dilakukan oleh nadir di Kabupaten Aceh Tengah yang mana perubahan atau pengalihan tanah wakaf hanya dilakukan secara lisan dan berdasarkan musyawarah adat menurut hukum adat di Kabupaten Aceh Tengah sendiri sering dilakukan dan mengenai apakah terdapat sanksi adat sendiri dalam permasalahan ini. Hal tersebut tidak terdapat pengaturan mengenai sanksi adat apabila terjadi perubahan peruntukan pada tanah wakaf yang telah diwakafkan oleh wakif hanya dilakukan secara lisan walaupun hal tersebut menyalahi aturan dalam UndangUndang Nomor 41 Tahun 2004 Tentang Wakaf maupun Hukum Islam dikarenakan menurut Hukum Adat di Kabupaten Aceh Tengah sendiri pewakafan dan peralihan peruntukan yang dilakukam secara adat dan secara lisan dianggap sah.

\footnotetext{
$\overline{10}$ Ilyas Ismail, "Sertifikat sebagai Alat Bukti Hak Atas Tanah dalam Proses Peradilan Kanun”, Jurnal Ilmu Hukum Vol. 13, No. 53, April (2011), 24.

11 Anwar Borahimah, "Kekuatan Hukum Akta Jual Beli yang Dibuat oleh Pejabat Pembuat Pembuat Akta Tanah Sementara, Rechtldee Jurnal Hukum, Vol. 8. No. 1, Juni (2013), 2.
} 


\section{Pelaksanaan Perwakafan Tanah di Kabupaten Aceh Tengah Ditinjau dari Hukum Islam dan Hukum Adat}

Wakaf yang diajarkan oleh Islam mempunyai sandaran ideologi yang amat kental dan kuat sebagai kelanjutan ajaran tauhid yaitu segala sesuatu yang berpuncak pada keyakinan terhadap keesaan Tuhan harus dibarengi dengan kesadaran akan perwujudan keadilan sosial. Sebagai salah satu instrumen ekonomis yang berdimensi sosial perwakafan tanah merupakan konsekuensi logis dari system kepemilikan dan islam. Ameer Ali menyebutkan wakaf merupakan cabang yang penting di dalam hukum Islam, sebab terjalin di dalamnya kehidupan ibadah dan sosial ekonomi muslimin. ${ }^{12}$

Pemilikan harta dalam islam disertai dengan pertanggung jawaban moral. Artinya segala sesuatu (harta benda) yang selama ini dimiliki oleh seseorang atau sebuah lembaga secara moral harus diyakini secara ideologis bahwa sebagian darinya menjadi hak bagi pihak lain yaitu untuk kesejahteraan umat. Pengelolaan dan pengembangan wakaf yang ada di Indonesia diperlukan komitmen bersama antara pemerintah, ulama dan masyarakat. Selain itu juga harus dirumuskan kembali mengenai berbagai hal yang berkenaan dengan wakaf, termasuk harta yang diwakafkan, peruntukkan wakaf dan nadir serta pengelolaan wakaf secara profesional. Selanjutnya wakaf harus diserahkan kepada orang-orang atau suatu badan khusus yang mempunyai kompetensi memadai sehingga bisa mengelola secara profesional dan amanah. ${ }^{13}$

Pelaksanaan wakaf di Kabupaten Aceh Tengah, pada umumnya menggunakan Hukum Islam sebagai pedoman proses pelaksanaan wakaf, sesuai dengan ajaran Islam untuk saling berbagi dan saling mensedekahkannya harta dijalan Allah SWT sangat dianjurkan, selain untuk keperluan pribadi dan keluarga dan juga untuk keperluan Agama. Dalam pelaksanaan wakaf ada aturan khusus yang mengatur tata cara pelaksanaan wakaf dan pertukaran peruntukkan wakaf guna tertibnya administrasi pencatatan tanah. Berdasarkan penjelasan Amrun Saleh pegawai Kementrian Agama Kabupaten Aceh Tengah bahwa tanah wakaf yang ada di Kabupaten Aceh Tengah pada umumnya secara Hukum Islam telah terlaksana dengan baik, terbukti dengan banyaknya masyarakat yang mewakafkan tanahnya dengan mendaftarkan tanah wakaf tersebut ke pihak yang berwenang sesuai dengan perundang-undangan seperti di kecamatan Bebesan Desa Keramat Mupakat. Namun masih banyak bermasalah dalam administrasi, yaitu terkait pemanfaatan tanah wakaf yang tidak sesuai dengan ikrar wakaf, pendaftaran wakaf ke Badan Pertanahan Nasional Kabupaten/Kota, berdasarkan data dan hasil wawancara dengan Amrun Saleh di Kantor Departemen Agama Kabupaten Aceh Tengah pada bagian Zakat dan Wakaf (ZAWA).

Perubahan pemanfaatanatastanahwakafdiKabupaten AcehTengahsecaraadatmasihsajaterjadi, hal ini pada dasarnya disebabkan ketidaktahuan masyarakat atas peraturan pergantian tanah wakaf. Perubahan pemanfaatan tanah wakaf hanya berdasarkan atas musyawarah desa, dalam menentukan peruntukan tanah wakaf di daerah Kabupaten Aceh Tengah hanya berdasarkan musyawarah desa, hal ini dikarenakan bahwa proses pergantian peruntukan tanah wakaf membutuhkan waktu yang sangat lama dan berbelit-belit sehingga mengharuskan mereka mengganti peruntukan tanah wakaf hanya dengan musyawarah desa.

Salah satu kasus yang terjadi di Desa Wih Nongkal Kecamatan Kute Penang, berdasarkan

\footnotetext{
12 Sofyan Mei Utama, "Penegakan Hukum Perwakafan di Indonesia”, Jurnal Hukum Mimbar Justitia, Vol. 3 No. 1, Juni (2017), 2.

13 Bashlul Hazami, "Peran dan Aplikasi Wakaf dalam Mewujudkan Kesejahteraan Umat di Indonesia”, Analisis, Vol. 16, No. 1, Juni (2016), 176.
} 
penjelasan Kepala Desa Wih Nongkal, tanah wakaf yang diwakafkan oleh Mahreje dibenarkan oleh nadir bahwa tanah wakaf yang berada di Desa Wih Nongkal yang telah terjadi perubahan sebanyak 3 (tiga) kali. Namun proses yang digunakan adalah hanya dengan mengucapkan secara lisan kepada lembaga adat desa (Sarak Opat) dan disaksikan oleh beberapa saksi artinya tidak memiliki bukti tertulis, padahal seperti diketahui Ikrar wakaf wajib dituangkan dalam Akta Ikrar Wakaf untuk mencegah terjadinya sengketa tanah wakaf yang disebabkan tidak jelasnya status dan kedudukan tanahnya, baik antara wakif dengan nadir ataupun antara keluarga wakif dengan umat Islam setempat dengan nadirnya. Disamping itu untuk mencegah terjadinya sengketa dalam kasus dimana setelah wakif meninggal dunia, sebagian ahli warisnya menolak dan tidak mengakui bahwa benda yang dimaksud adalah benda wakaf. ${ }^{14}$ Kasus ini juga yang terjadi di Desa Keramat Mufakat Kecamatan Bebesan yang mana perubahan status tanah wakaf yang ditukar oleh Pemerintah Kabupaten Aceh sudah dilaporkan dan sudah diganti Ikrar Wakaf oleh KUA kecamatan Bebesan sedangkan perubahan kedua yang terjadi hanya berdasarkan kesepatan dan musyawarah adat desa dan tidak di laporkan mengenai perubahan tanah wakaf kepada pihak yang berwenang agar Akta Ikrar Wakafnya di ganti.

Wakaf merupakan salah satu lembaga sosial ekonomi Islam yang sangat penting dalam pembangunan masyarakat Indonesia, namun hal ini tidak atau belum berjalan dengan optimal jika dalam pelaksanaannya belum sesuai dengan Undang-Undang dan peraturan Pemerintah tentang hukum wakaf. Pada kasus tanah wakaf pembangunan awal tidak ada wacana bagaimana akan ada perubahan atau peralihan tanah wakaf, namun setelah beberapa tahun terjadi perubahan pembangunan masyarakat merasa membutuhkan hak atas tanah wakaf tersebut dengan memberikan pendapatnya tentang mengubah tanah wakaf yang dijadikan fasilitas masjid (meunasah) menyambung menjadi tempat pengajian dan akhirnya menjadi tanah untuk perkuburan,

Pada perjanjian peruntukan tanah wakaf Badan Pertanahan Nasional hanya terkait proses legilasinya saja yaitu hanya terkait pada bukti atas hak yang kuat mengenai penerbitan sertifikat bahwa tanah itu adalah tanah wakaf sebab proses perwakafan sampai diterbitkannya ikrar wakaf yang kemudian akan dituangkan dalam akta PPAIW yang dilakukan di Kantor Urusan Agama di Kecamatan setempat. Oleh karena itu, jika terjadi perubahan peruntukan tanah wakaf maka Ikrar Wakaf terlebih dahulu diperbaharui terkait dengan perubahan peruntukan tanah wakaf dan jika terjadi perubahan pada data fisik atau data objek tanah yang telah terdaftar disitulah peran Badan Pertanahan yang mewajibkan mendaftarkan perubahan tersebut kepada Kantor Pertanahan

Peralihan fungsi tanah wakaf ini hanya dilakukan secara musyawarah dengan nadir dan tokoh masyarakat yang mana di Kabupaten Aceh Tengah terdapat Sarak Opat yang dianggap mengetahui asal usul tanah tersebut, dan tidak dilakukan sesuai dengan Pasal 11 ayat (3) Peraturan Pemerintah Nomor 28 Tahun 1977 Tentang Perwakafan Tanah Milik Tentang Perubahan Wakaf Hak Milik yaitu perubahan status tanah milik yang telah diwakafkan dan perubahan penggunaan sebagai akibat ketentuan tersebut dalam ayat (2) harus dilaporkan oleh nadir kepada Bupati/Walikota Kepala Daerah atau Kepala Sub Direktorat Agraria setempat untuk mendapatkan penyelesaiam lebih lanjut.

Dalam hal ini yang dipermasalahkan bagaimana pada saat Ikrar wakaf yaitu tanah diperuntukkan sebagai jalan umum dan telah dibuktikan dengan Akta Ikrar Wakaf yang telah dibuat pada kesepakatan tanpa paksaan atau terpaksa dari pihak lain dan tanpa ada kata pengganti tanah wakaf tersebut

\footnotetext{
${ }^{14}$ Samsidar, "Urgensi Alat Bukti Akta Ikrar Wakaf dalam Penyelesaian Sengketa Perwakafan”, Jurnal Supermasi, Vol. 11, No. 2,
} Oktober (2016), 139. 
apabila dalam beberapa tahun kemudian. Hal ini membiarkan tugas dan tanggung jawab seorang nadir, yang mana seharusnya nadir memiliki kewajiban untuk mengelola dan mengembangkan tanah wakaf sesuai dengan tujuan dan fungsi namun karena permasalahan ini nadir menjadi satusatunya penanggung jawab yang harus semua tanah wakaf bisa dioptimalkan sesuai dengan apa yang diikrarkan oleh wakif.

Tanah wakaf yang terdapat di kalangan masyarakat di Kabupaten Aceh Tengah sebagian besar proses ikrar wakif hanya dalam bentuk lisan. Proses yang sesuai dengan peraturan perundangundangan masih sangat kurang. Sehingga banyak terjadi sengketa terhadap tanah wakaf karema tidak ada suatu bukti yang kuat terhadap tanah wakaf. Disebabkan karena ini dengan mudah tanah wakaf terjadi perubahan peruntukanya. Tanah wakaf yang terdapat di Kecamatan Kute Penang maupun Kecamatan Bebesan belum menjalankan prosedur yang harus ditempuh dalam perubahan peruntukan tanah wakaf. Maka untuk itu diperlukan pihak-pihak yang terkait dalam tanah ini dapat bekerjasama dalam pengelolaan peruntukan tanah wakaf agar pengelolaan tanah wakaf dapat dilakukan secara maksimal.Jika terjadi perubahan peruntukan tanah wakaf maka ikrar wakaf terlebih dahulu diperbaharui terkait dengan perubahan peruntukkan tanah wakaf dan jika terjadi perubahan pada data fisik atau data objek tanah yang telah terdaftar disitulah peran Badan Pertanahan yang mewajibkan mendaftarkan perubahan tersebut kepada Kantor Pertanahan.

Pelaksanaan perjanjian peruntukkan tanah wakaf kedepannya akan menuai berbagai kendala seperti perubahan peruntukkan tanah wakaf namun tidak mengikuti prosedur perubahan peruntukkan tanah wakaf yang sesuai peraturan perundang undangan sehingga dapat merugikan berbagai pihak baik dalam mewujudkan tertib administrasi dalam pembuatan ikrar wakaf maupun dalam pemanfaatan peruntukkan tanah wakaf.

Pejabat Pembuatan Akta Ikrar Wakaf atas nama nadir mendaftarkan harta benda wakaf kepada instansi yang berwenang paling lambat 7 (tujuh) hari kerja sejak akta ikrar wakaf ditandatangani, hal ini terdapat dalam Pasal 32 Undang-Undang Nomor 41 Tahun 2004 Tentang Wakaf. Dalam Pasal 38 Undang-Undang Nomor 41 Tahun 2004 Tentang Wakaf juga disebutkan bahwa Menteri dan Badan Wakaf Indonesia mengumumkan kepada masyarakat harta benda wakaf yang telah terdaftar.

Pelaksanaan peralihan peruntukan tanah wakaf berdasarkan Hukum Adat Aceh yang terjadi di Kabupaten Aceh Tengah, Kecamatan Kute Penang dan Kecamatan Bebesan di pandang menurut Undang-Undang Nomor 41 Tahun 2004 Tentang Wakaf adalah tidak dapat dibenarkan, karena dalam kebiasannya perubahan peruntukan tanah wakaf di Kabupaten Aceh Tengah dilaksanakan secara lisan dan diikrarkan kepada perorangan dan terhadap pelaksanaan terhadap tanah wakaf tersebut tidak adanya pendaftaran terhadap tanah wakaf tersebut, maka yang terjadi tidak adanya transparasi terhadap pergantian tanah wakaf sesuai dengan Undang-Undang.

Demi tercapainya tujuan wakaf dan fungsi wakaf tanah yang dikelola oleh nadir harus sesuai dengan tujuan akad wakaf sebagaimana tertulis dalam ikrar wakaf yang diucapkan oleh wakif. Oleh karena itu seharusnya wakif mengucapkan ikrar wakaf dengan jelas kepada nadir dihadapan Pejabat Pembuat Akta Ikrar Wakaf (PPAIW) baik berupa tulisan ataupun lisan dengan disaksikan 2 (dua) orang saksi agar Akta Ikrar Wakaf dapat dikeluarkan, karena Ikrar Wakaf adalah sebagai kelengkapan untuk membuat dokumen pendaftaran tanah wakaf. Akta Ikrar Wakaf adalah sebagai kelengkapan untuk membuat dokumen pendaftaran tanah wakaf. 


\section{Penutup}

Berdasarkan hasil analisis di atas maka dapat disimpulkan bahwa kedudukan hukum tanah wakaf yang telah diwakafkan tidak dapat dipergunakan apabila tidak sesuai dengan ikrar wakaf, namun ada pengecualian tanah wakaf bisa dirubah peruntukannya dan harus mengikuti prosedur perubahan yang ditetapkan oleh Undang-Undang Nomor 41 Tahun 2004 Tentang Wakaf. Tanah wakaf yang telah diwakafkan menurut syariah, tetapi tidak disertifikatkannya membuat kedudukan tanah tersebut lemah secara hukum. Tanah wakaf yang diwakafkan hanya secara lisan dan tidak terdapat akta wakaf, belum memiliki perlindungan hukum, tetapi sah menurut Hukum Islam. Mengenai sanksi adat yang dapat diterima oleh nadir karena mengalihkan tanah wakaf berdasarkan musyawarah adat dan secara lisan tidak terdapat pengaturan di Hukum Adat Gayo sendiri dikarenakan menurut Hukum Adat di Kabupaten Aceh Tengah sendiri pewakafan dan peralihan peruntukan yang dilakukan secara adat dan secara lisan dianggap sah.

Selain itu, pelaksanaan perwakafan tanah yang terdapat di Kabupaten Aceh Tengah secara Hukum Islam telah terlaksana dengan benar, namun secara berdasarkan hukum administrasi negara belum terlaksana dengan maksimal karena proses perwakafan banyak yang belum didaftarkan kepada Pejabat Pembuat Akta Wakaf (PPAIW).

Tampaknya, seperti di banyak tempat di Indonesia, warga Muslim di Kabupaten Aceh Tengah masih mempraktikkan aturan-aturan wakaf berdasarkan kebiasaan-kebiasaan setempat saja dilandasi saling percaya antar pihak.

\section{Daftar Pustaka}

Anshori, Abdul Ghofur. Hukum dan Praktik Perwakafan di Indonesia. Yogyakarta: Pilar Media, 2005.

Ardani, Mira Novana. "Kepemilikan hak atas tanah bagi orang asing di Indonesia." Jurnal Law Reform Vol. 13, No. 2, (2017).

Borahimah, Anwar. "Kekuatan Hukum Akta Jual Beli yang Dibuat oleh Pejabat Pembuat Pembuat Akta Tanah Sementara." Rechtldee Jurnal Hukum, Vol. 8. No. 1, Juni (2013).

Hazami, Bashlul. "Peran dan Aplikasi Wakaf dalam Mewujudkan Kesejahteraan Umat di Indonesia." Analisis, Vol. 16, No. 1, Juni (2016).

Kusumaatmadja, Mochtar dan Sidharta, B. Arief. Pegantar Ilmu Hukum Suatu Pengenalan Pertama Ruang Lingkup Berlakunya Hukum. Bandung: Alumni, 2000.

Hidayatullah, Syarif. "Wakaf Uang Dalam Perspektif Hukum Islam dan Hukum Positif di Indonesia." Salam: Jurnal Sosial \& Budaya Syar-i Vol. 3 No. 1 (2016).

Ismail, Ilyas. "Sertifikat sebagai Alat Bukti Hak Atas Tanah dalam Proses Peradilan." Kanun Jurnal Ilmu Hukum Vol. 53, No. 13, April (2011).

Lubis, Syaddan Dintara; Lubis, Muhammad Yamin; Barus, Utary Maharany; Sembiring, Rosnidar. "Hubungan Hukum Pengelolaan Wakaf antara Nazhir dan Badan Wakaf Indonesia Provinsi Sumatra Utara terhadap Tanah Wakaf yang belum Terdaftar: Studi di Kota Medan." USU Law Journal, Vol. 3, No. 3, November (2015).

Samsidar, "Urgensi Alat Bukti Akta Ikrar Wakaf dalam Penyelesaian Sengketa Perwakafan." Jurnal Supermasi, Vol. 11 No. 2, Oktober (2016). 
Soekanto, Soerjono. Pengantar Penelitian Hukum. Jakarta: UI Press, 2002.

Suhadi, Imam. Wakaf Untuk Kesejahteraan Umat. Yogyakarta: Dana Bhakti Prima Jasa, 2002.

Ter Haar, Asas-asas dan Susunan Hukum Adat. Jakarta: Pradnya Paramita, 1983.

Usman, Rachmadi. Hukum Perwakafan Di Indonesia. Jakarta: Sinar Grafika, 2009.

Utama, Sofyan Mei. “Penegakan Hukum Perwakafan di Indonesia.” Jurnal Hukum Mimbar Justitia, Vol. 3 No. 1, Juni (2017). 
